Gut, 1972, 13, 805-811

\title{
Effect of eating on motility of the pelvic colon in constipation or diarrhoea ${ }^{1}$
}

\author{
SHEILA L. WALLER, J. J. MISIEWICZ, AND NANCY KILEY \\ From the Medical Research Council Gastroenterology Unit, Central Middlesex Hospital, London
}

SUMMARY Pelvic colonic pressures were recorded before, during, as well as after a meal in patients with non-specific diarrhoea (12) or constipation (14), who were selected according to strict clinical criteria of bowel habit. In the basal state diarrhoeal patients as a group had significantly less colonic activity than constipated patients, but the overlap was considerable. During the meal colonic activity was strikingly increased in diarrhoea, but returned to basal levels immediately after the meal; no such response was observed in constipation. It is suggested that this brief segmental response of the pelvic diarrhoeal colon may be inadequate to prevent entry of faeces into the rectum and the desire to defaecate, following a meal.

Constipation or diarrhoea are common symptoms but the changes of colonic motor activity that may accompany these disorders are still poorly understood. It is believed that segmenting intraluminal pressures are non-propulsive and that such activity is more likely to delay rather than increase colonic transit. It has been suggested that diarrhoea is associated with low levels of colonic segmenting pressure activity whilst constipated subjects have high levels of segmentation (Kern, Almy, Abbot, and Bogdonoff, 1951 ; Spriggs, Code, Bargen, Curtiss, and Hightower, 1951; Chaudhary and Truelove, 1961; Connell, 1962). These considerations have led to the hypothesis of paradoxical motility of the colon as constipation and diarrhoea (Connell, 1962). Whilst the hypothesis is attractive, it has not yet been proven experimentally in patients with clearly defined alterations in bowel habit.

Eating affects the motility of the colon and Holdstock and Misiewicz (1970) have recently shown that increased colonic segmentation occurs during as well as after a meal. Many patients with diarrhoea notice a close relationship between eating and the desire to defaecate and this suggests that their colonic motility responses to a meal may be abnormal. We therefore compared the basal intraluminal colonic pressure activity with the changes both during and after a meal in patients with non-

${ }^{1}$ Presented in part at the Third International Symposium on Gastroenterology Motility, Stockholm, 1971.

Received for publication 27 Jnly 1972. specific diarrhoea or constipation who were selected according to strict diagnostic criteria.

\section{Methods and Patients}

Diarrhoea was defined as an intermittent or continuous increase in bowel frequency to three or more times/day, the stools being semi-solid or watery (Table I). Constipation was defined as a decrease in the number of stools passed to less than three/week and/or the passage of hard stools often covered in mucus (Table II). These frequencies were chosen on the basis of a previous study of bowel habit (Connell, Hilton, Irvine, Lennard-Jones, and Misiewicz, 1965). Only patients who had either constipation or diarrhoea were studied: patients with alternating diarrhoea and constipation were excluded. All the patients were thoroughly investigated to exclude any gastrointestinal, metabolic, infective, or drug-induced cause for the alteration in bowel habit: they were therefore regarded as cases of the irritable bowel syndrome (Waller and Misiewicz, 1969) or simple constipation.

All drugs were stopped for at least three days before the study. The patient was fasted overnight. On the morning of the study three air-filled $7 \times 10$ $\mathrm{mm}$ balloons were placed at approximately 20,15 , and $10 \mathrm{~cm}$ from the anal margin under sigmoidoscopic control and intraluminal colonic pressures were recorded as described previously (Misiewicz, Waller, and Eisner, 1966). The presence or absence of faeces in the rectum and colon was noted. After 
sigmoidoscopy the patient sat comfortably so that no change of posture was necessary when the meal was served. Half an hour was allowed to elapse before recording began. After a 30-minute basal record the patient was given a meal consisting of eggs, bread, butter, and fruit and including two cups of tea. No patient found the meal distasteful. Intraluminal pressure recording was continued during and for the $\mathbf{3 0}$ minutes immediately following the meal.

Three leads were defined: lead $\mathrm{I}$ in which the balloon lay at $20 \pm 2 \mathrm{~cm}$, lead II at $15 \pm 2 \mathrm{~cm}$, and lead III at $10 \pm 2 \mathrm{~cm}$ from the anal margin. The pressure traces were processed in an analogue to digital converter and analysed by computer (Misiewicz, Waller, Healy, and Piper, 1968). The control and postmeal periods were each analysed in three consecutive 10-minute intervals and then pooled to give the 30 -minute pre- and postmeal periods. The meal periods were analysed as a whole and the time taken to eat the meal was noted.

The primary variables available for statistical analysis were: the number of pressure events/ minute, the mean height of the pressure peaks (in $\mathrm{cm}$ of water), and the mean duration of pressure events (in seconds). Derived (or secondary) variables were the percentage duration of activity, calculated from the number and duration of pressure events and a numerical index of total colonic activity (average intensity) calculated from the height of the pressure peaks and the percentage duration of activity (Misiewicz et al, 1968; Waller and Misiewicz, 1970). Another variable was the percentage of fast wave activity, ie, the number of pressure events with three or more peaks which occurred at a mean rate of five or more peaks/minute (Misiewicz et al, 1968).
Statistical analysis of the data was carried out within the two groups by two-way analysis of variance, and between the groups by comparison of the means. The data for fast wave activity were analysed by combining the three leads in each group and the significance was tested by chi squared.

\section{Results}

Twenty-six patients were studied. Seven of the 12 patients with diarrhoea had symptoms at the time of study (Table I). Fourteen patients suffered from constipation, eight had the irritable bowel syndrome, and six simple constipation. The majority had their bowels open less than three times/week, but only five took laxatives regularly. Twelve were noted to have symptoms at the time of study (Table II). In one diarrhoeal and four constipated patients sigmoidoscopy was not possible beyond $15 \mathrm{~cm}$ due to severe spasm. Data from either lead II or III in four patients have been discarded for technical reasons.

\section{BASAL ACTIVITY}

Within each group there were no significant differences in any variable in any lead on comparison of the three 10-minute basal periods. This suggested that the observations were adequately controlled.

During the basal period the mean average intensity was significantly higher in constipated patients than in those with diarrhoea in all three leads, the difference being most pronounced in lead I, but the overlap between the two groups was considerable. Similar results were recorded for the percentage duration of activity (Table III). These differences in average intensity and percentage dura-

\begin{tabular}{|c|c|c|c|c|c|c|c|}
\hline No. & Sex & Age & $\begin{array}{l}\text { Length of } \\
\text { History }(y r)\end{array}$ & $\begin{array}{l}\text { Bowel Habit and Character of } \\
\text { Faeces }\end{array}$ & $\begin{array}{l}\text { Pain as a } \\
\text { Symptom }\end{array}$ & $\begin{array}{l}\text { Diarrhoea Present } \\
\text { at Time of Study }\end{array}$ & $\begin{array}{l}\text { Faeces in } \\
\text { Rectum }\end{array}$ \\
\hline $\begin{array}{l}1 \\
2 \\
3\end{array}$ & $\begin{array}{l}\mathbf{M} \\
\mathbf{M} \\
\mathbf{F}\end{array}$ & $\begin{array}{l}59 \\
42 \\
35\end{array}$ & $\begin{array}{r}20 \\
10 \\
6\end{array}$ & $\begin{array}{l}>3 / \text { day Fluid, continuous } \\
>3 / \text { day Semi-solid, intermittent } \\
>3 / \text { day Fluid or semi-solid, } \\
\text { continuous }\end{array}$ & $\begin{array}{l}0 \\
+ \\
0\end{array}$ & $\begin{array}{l}\text { Present } \\
\text { Not present } \\
\text { Present }\end{array}$ & $\begin{array}{l}\text { Nil } \\
\text { Nil } \\
\text { Yes, soft }\end{array}$ \\
\hline $\begin{array}{l}4 \\
5\end{array}$ & $\begin{array}{l}\mathbf{F} \\
\mathbf{F}\end{array}$ & $\begin{array}{l}59 \\
26\end{array}$ & $\begin{array}{l}7 \\
1\end{array}$ & $\begin{array}{l}>3 / \text { day Semi-solid, intermittent } \\
>3 / \text { day Fluid or semi-solid, } \\
\text { continuous }\end{array}$ & $\begin{array}{l}\mathbf{0} \\
\mathbf{0}\end{array}$ & $\begin{array}{l}\text { Not present } \\
\text { Present }\end{array}$ & $\begin{array}{l}\text { Yes, soft } \\
\text { Yes, soft }\end{array}$ \\
\hline 6 & $\mathbf{F}$ & 35 & 2 & $\begin{array}{l}>3 / \text { day Fluid or semi-solid, } \\
\text { continuous }\end{array}$ & + & Present & Nil \\
\hline 7 & $\mathbf{M}$ & 34 & 15 & $\begin{array}{l}\text { Up to } 3 / \text { day, semi-solid, } \\
\text { intermittent }\end{array}$ & + & Not present & Yes, soft \\
\hline $\begin{array}{l}8 \\
9\end{array}$ & $\begin{array}{l}\mathbf{F} \\
\mathbf{M}\end{array}$ & $\begin{array}{l}20 \\
22\end{array}$ & 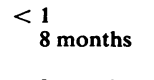 & $\begin{array}{l}>3 / \text { day Fluid, intermittent } \\
>3 / \text { day Fluid or semi-solid, } \\
\text { continuous }\end{array}$ & $\begin{array}{l}\mathbf{0} \\
\mathbf{0}\end{array}$ & $\begin{array}{l}\text { Not present } \\
\text { Present }\end{array}$ & $\begin{array}{l}\text { Yes, soft } \\
\text { Yes, fluid }\end{array}$ \\
\hline $\begin{array}{l}10 \\
11 \\
12\end{array}$ & $\begin{array}{l}\mathbf{F} \\
\mathbf{M} \\
\mathbf{M}\end{array}$ & $\begin{array}{l}64 \\
50 \\
20\end{array}$ & $\begin{array}{l}3 \text { months } \\
1 \\
8 \text { months }\end{array}$ & $\begin{array}{l}>3 \text { /day Semi-solid, intermittent } \\
>3 \text { day Semi-solid, intermittent } \\
>\text { 3/day Semi-solid, intermittent }\end{array}$ & $\begin{array}{l}+ \\
0 \\
+\end{array}$ & $\begin{array}{l}\text { Present } \\
\text { Present } \\
\text { Not present }\end{array}$ & $\begin{array}{l}\text { Yes, soft } \\
\text { Nil } \\
\text { Yes, soft }\end{array}$ \\
\hline
\end{tabular}

Table I Clinical details of diarrhoeal patients ${ }^{1}$

${ }^{1}$ All patients had the irritable bowel syndrome

'Indicates sigmoidoscopy only possible to $15 \mathrm{~cm}$ 


\begin{tabular}{|c|c|c|c|c|c|c|c|c|}
\hline No. & Sex & Age & $\begin{array}{l}\text { Length of } \\
\text { History }(y r)\end{array}$ & $\begin{array}{l}\text { Bowel Habit and Character } \\
\text { of Faeces }\end{array}$ & $\begin{array}{l}\text { Pain as a } \\
\text { Symptom }\end{array}$ & $\begin{array}{l}\text { Constipation } \\
\text { Present at Time } \\
\text { of Study }\end{array}$ & $\begin{array}{l}\text { Faeces in } \\
\text { Rectum }\end{array}$ & $\begin{array}{l}\text { Regular } \\
\text { Laxatives }\end{array}$ \\
\hline 2 & $\mathbf{M}$ & 31 & 4 & $1-2 /$ day small, hard, mucus + & + & Present & Yes & No \\
\hline 3 & $\mathbf{F}$ & 28 & 2 & Every 3rd day, hard & + & Not noted & Not noted & No \\
\hline 4 & $\mathbf{M}$ & 56 & 9 & $<$ every 3rd day, hard & + & Present & $\mathrm{Nil}^{2}$ & No \\
\hline 5 & $\mathbf{F}$ & 48 & $1 \frac{1}{2}$ & $\begin{array}{l}2-3 / \text { day, small, hard, } \\
\text { mucus }+\end{array}$ & + & Present & $\mathrm{Nil}$ & No \\
\hline 6 & $\mathbf{F}$ & 23 & 11 & $<$ every 3 rd day, hard & + & Present & Yes $^{2}$ & No \\
\hline 7 & $\mathbf{F}$ & 42 & 5 & $<$ every 3 rd day, hard & + & Present & Nil & No \\
\hline 8 & $\mathbf{M}$ & 74 & 5 & $\begin{array}{l}\text { Alternate days, small hard, } \\
\text { mucus }+\end{array}$ & + & Present & Yes $^{2}$ & Yes \\
\hline 9 & $\mathbf{F}$ & 44 & $\begin{array}{l}\text { All life, worse } \\
\text { for } 3 \text { months }\end{array}$ & $<$ every 3 rd day, hard & $\mathbf{0}$ & Not noted & Not noted & Yes \\
\hline 10 & $\mathbf{M}$ & 40 & 13 & $<$ every 3 rd day, hard & $\mathbf{0}$ & Present & Yes & No \\
\hline 11 & $\mathbf{F}$ & 45 & 30 & $<$ every 3rd day, hard & $\mathbf{0}$ & Present & Nil & Yes \\
\hline 12 & $\mathbf{F}$ & 21 & 10 & $<$ every 3 rd day, hard & 0 & Present & $\mathrm{Nil}^{2}$ & No \\
\hline 14 & $\mathbf{F}$ & 23 & 20 & $<$ every 3 rd day, small, hard & 0 & Present & Nil & Yes \\
\hline
\end{tabular}

Table II Clinical details of constipated patients $\mathbf{1}^{\mathbf{1}}$

1Patients 1-8 had the irritable bowel syndrome, patients 9-14 had simple constipation 'Indicates sigmoidoscopy only possible to $15 \mathrm{~cm}$

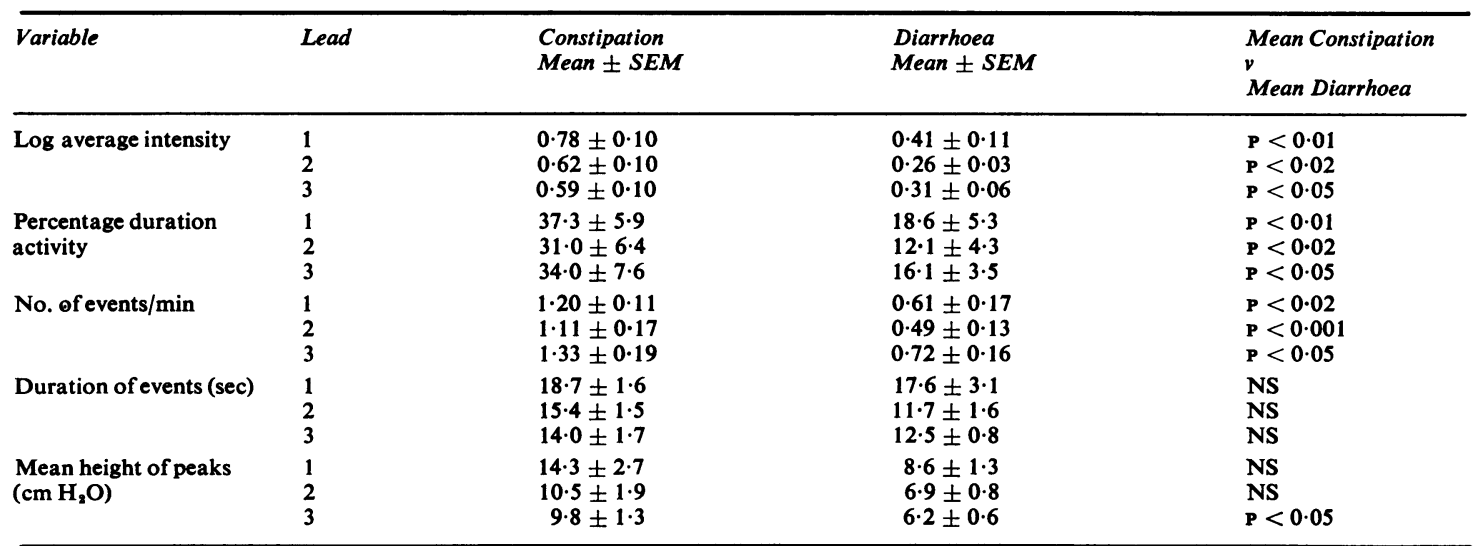

Table III Colonic activity during the basal period

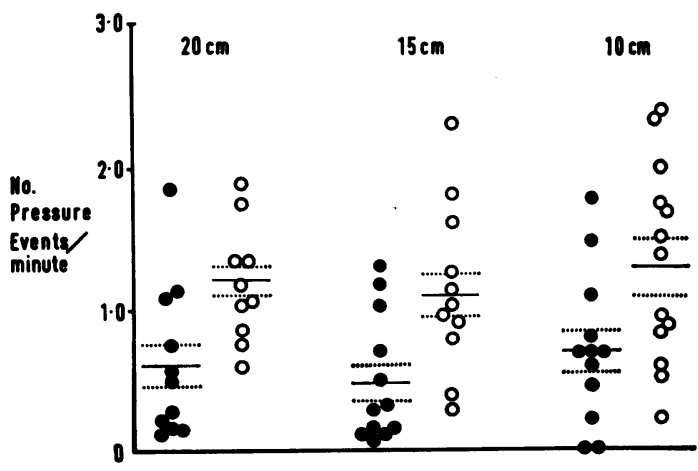

Fig. 1 No. of pressure events/minute during basal 30minute period in constipated $(0)$ and diarrhoeal $(O)$ patients. Horizontal lines = mean and SEM. tion of activity were due solely to the significantly greater mean frequency of pressure waves in constipation, the other primary variables being no different for the two groups (Fig. 1, Table III).

ALTERATIONS IN COLONIC ACTIVITY DURING AND AFTER A MEAL

The time taken to eat the meal was similar for the patients with diarrhoea or constipation (13.4 $\pm 3 \cdot 2$ and $13.5 \pm 3.6$ minutes respectively).

In patients with diarrhoea colonic motility increased significantly in all three leads during the ingestion of the meal. This increase was observed with respect to all the variables with the exception of the mean duration of pressure events (Table IV). The response was greatest in lead I (Fig. 2) and at 


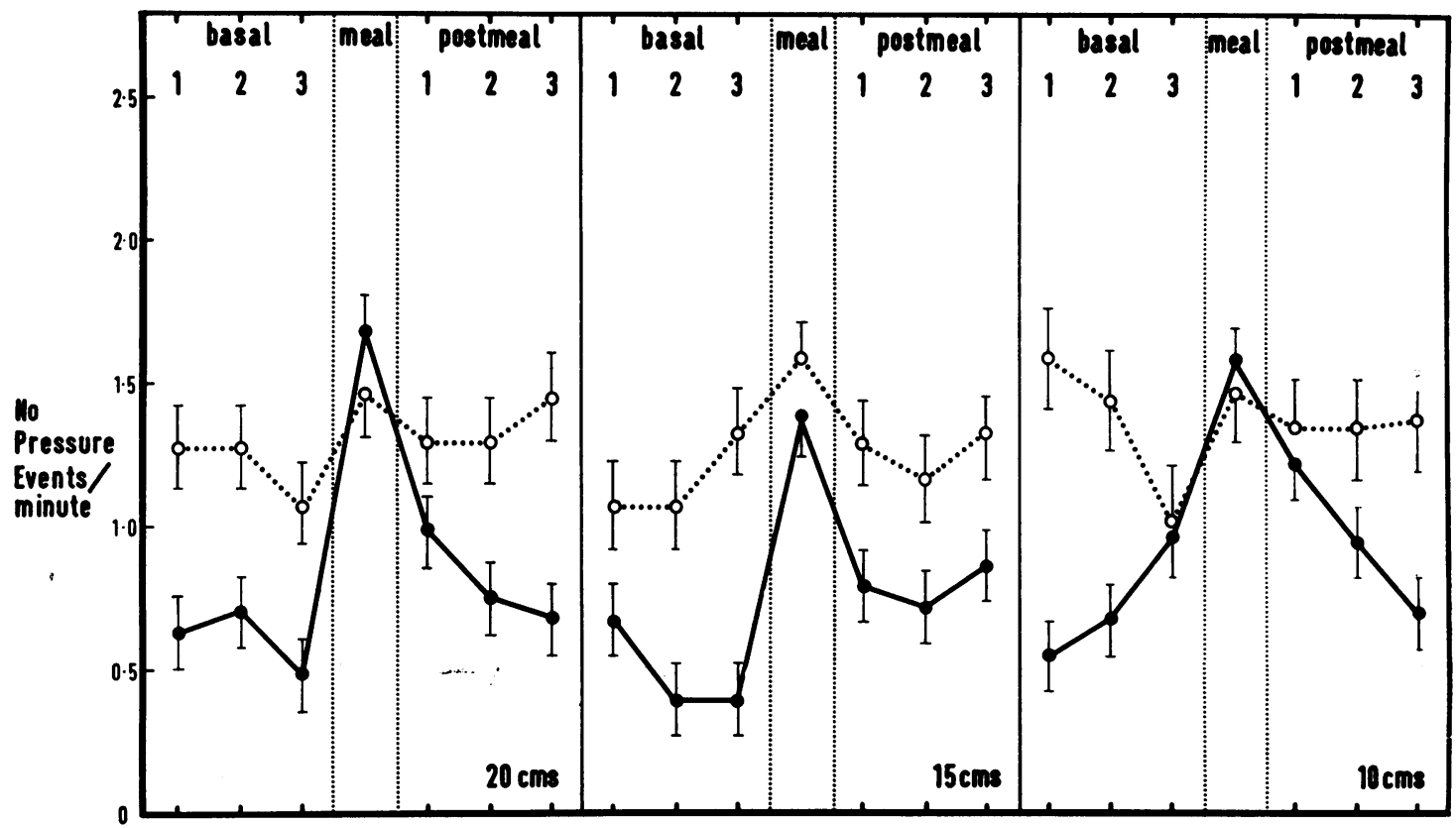

Fig. 2 No. of pressure events/minute during three basal 10-minute periods, the meal, and the three postmeal 10 minutes. $\mathrm{O}=$ mean for constipated patients; $\mathrm{O}=$ mean for diarrhoeal patients. Horizontal lines $=S E M$.

\begin{tabular}{|c|c|c|c|c|}
\hline Variable & Lead & $\begin{array}{l}\text { Constipation } \\
\text { Mean } \pm S E M\end{array}$ & $\begin{array}{l}\text { Diarrhoea } \\
\text { Mean } \pm S E M\end{array}$ & $\begin{array}{l}\text { Mean Constipation } \\
v \\
\text { Mean Diarrhoea }\end{array}$ \\
\hline Log average intensity & $\begin{array}{l}1 \\
2 \\
3\end{array}$ & $\begin{array}{l}0.09 \pm 0.08 \\
0.17 \pm 0.08 \\
0.21 \pm 0.10\end{array}$ & $\begin{array}{l}0.50 \pm 0.124 \\
0.42 \pm 0.10^{4} \\
0.21 \pm 0.09^{4}\end{array}$ & $\begin{array}{l}\text { P }<0.001 \\
\text { NS } \\
\text { NS }\end{array}$ \\
\hline $\begin{array}{l}\text { Percentage duration } \\
\text { activity }\end{array}$ & $\begin{array}{l}1 \\
2 \\
3\end{array}$ & $\begin{aligned} 7 \cdot 1 & \pm 5 \cdot 2 \\
13 \cdot 0 & \pm 4 \cdot 3^{2} \\
4 \cdot 9 & \pm 5 \cdot 7\end{aligned}$ & $\begin{array}{l}31 \cdot 34 \pm 6 \cdot 6^{4} \\
21 \cdot 9 \pm 6 \cdot 2^{3} \\
15 \cdot 1 \pm 6.0^{8}\end{array}$ & $\begin{array}{l}P<0.01 \\
\text { NS } \\
\text { NS }\end{array}$ \\
\hline No. of events/min & $\begin{array}{l}1 \\
2 \\
3\end{array}$ & $\begin{array}{l}0.23 \pm 0.21 \\
0.40 \pm 0.20 \\
0.10 \pm 0.21\end{array}$ & $\begin{array}{l}1.07 \pm 0.15^{4} \\
0.83 \pm 0.16^{4} \\
0.89 \pm 0.29^{2}\end{array}$ & $\begin{array}{l}P<0.01 \\
N S \\
P<0.05\end{array}$ \\
\hline Duration of events (sec) & $\begin{array}{l}1 \\
2 \\
3\end{array}$ & $\begin{array}{r}-0.10 \pm 1.9 \\
1.7 \pm 1.7 \\
1.6 \pm 2.5\end{array}$ & $\begin{array}{r}0.5 \pm 2.2 \\
2.7 \pm 1.9 \\
-0.5 \pm 0.7\end{array}$ & $\begin{array}{l}\text { NS } \\
\text { NS } \\
\text { NS }\end{array}$ \\
\hline $\begin{array}{l}\text { Mean height of peaks } \\
\left(\mathrm{cm} \mathrm{H}_{2} \mathrm{O}\right)\end{array}$ & $\begin{array}{l}1 \\
2 \\
3\end{array}$ & $\begin{array}{l}1.4 \pm 2.3 \\
1.9 \pm 1.2 \\
2.6 \pm 1.8\end{array}$ & $\begin{array}{l}5.7 \pm 2 \cdot 1^{4} \\
5.1 \pm 2 \cdot 0^{1} \\
0.34 \pm 0.62\end{array}$ & $\begin{array}{l}\text { NS } \\
\text { NS } \\
\text { NS }\end{array}$ \\
\hline
\end{tabular}

Table IV Colonic response during meals (response for each patient being the difference between prandial and basal values for the variable and lead under consideration)

Superscripts indicate significant differences between basal and meal periods within the groups.

${ }^{1} P<0.05{ }^{2} P<0.01 \quad{ }^{3} P<0.002 \quad{ }^{4} P<0.001$

this level it began immediately or within three minutes of the start of the meal in $82 \%$ of patients with diarrhoea. Pressure activity in the postmeal period did not differ significantly from that before the meal nor were the 10-minute postmeal periods different from one another, indicating an abrupt return of colonic activity to basal levels after the meal. In constipated patients, on the other hand, there were no consistent changes either during the meal (Table IV) or in the $\mathbf{3 0}$ minutes immediately after the meal, nor when the three 10-minute postmeal periods were compared with each other.

These dissimilarities in the pattern of motor activity during a meal are emphasized by analysis 


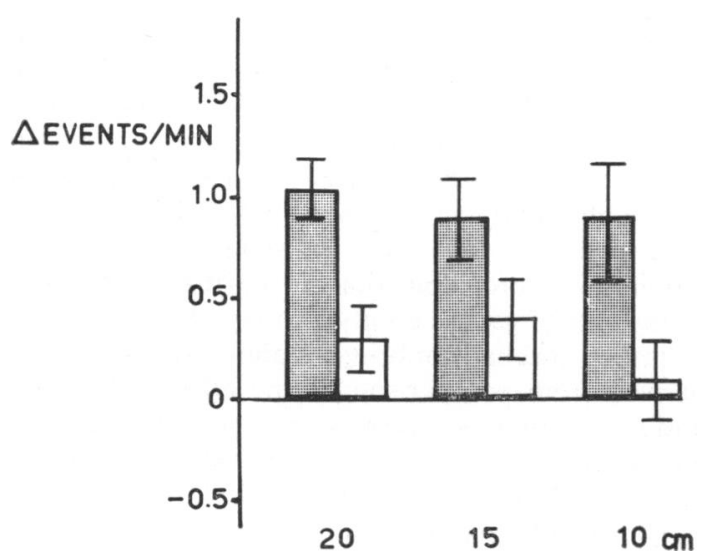

Fig. 3 Increase in the number of pressure events/minute during the meal. Crosshatched areas : diarrhoea. White areas : constipation. Horizontal lines $=$ SEM.

of the magnitude of the response in the two clinical groups. Response in diarrhoea was significantly higher in lead I whether judged in terms of average intensity $(P<0.001)$, percentage duration of activity $(\mathrm{P}<0.01)$, or the frequency of pressure events $(P<0.01$, Fig. 3). Responses recorded in leads II and III did not generally differentiate between the two groups at a significant level (Table IV).

\section{FAST WAVE ACTIVITY}

The pressure traces of four diarrhoeal and four constipated patients showed no fast wave activity during any period of study. More constipated patients $(50 \%)$ had fast wave activity during the basal period than diarrhoeal patients $(20 \%)$ and this difference was significant $(P<0.05)$. During the meal there was a marked increase in fast wave activity in diarrhoeal patients $(P<0.05)$ whilst in constipated patients the fast wave activity decreased but not significantly. However, the difference in fast wave activity between the two groups during the meal did not reach significant levels. In the postprandial period fast wave activity was similar to that in the basal period for the two groups. The functional significance of fast wave activity is at present not clear.

THE EFFECT OF FAECES IN THE RECTUM, PAIN, OR THE PRESENCE OF SYMPTOMS AT THE TIME OF STUDY ON COLONIC MOTOR ACTIVITY

Two thirds of diarrhoeal patients, but only one third of constipated patients had faeces in the rectum at sigmoidoscopy (Tables I and II). Contrary to what might have been expected there was no correlation between the presence of faeces in the rectum and the level of basal motor activity. The response during eating tended to be greater in those patients whose rectums were empty at sigmoidoscopy but the difference was not significant.

In diarrhoeal patients the mean basal activity was not affected by the presence or absence of symptoms at the time of study. The mean response to a meal was greater in those patients who had symptoms, but this difference reached significance only in lead I for the percentage duration of activity $(P<0.01)$ and in lead II for the number of events/ minute $(\mathrm{P}<0.05)$.

The basal motility of patients with pain in either group did not differ from those who did not have pain as a symptom. Diarrhoeal patients who had pain showed less response to a meal than those with painless diarrhoea but the difference was again only significant for the percentage duration of activity in lead I $(P<0.05)$. On the other hand constipated patients with pain had a greater response during a meal than those with simple constipation but this did not reach significant levels.

\section{Discussion}

The present results show for the first time that in patients with a rigorously defined alteration of bowel habit the response of the pelvic colon during eating differs in constipation and diarrhoea. Both the frequency and amplitude of colonic pressure waves were markedly increased during the meal in diarrhoeal patients, but returned to the low basal levels as soon as the meal was finished: in constipation no such response occurred during the meal, nor was the activity significantly increased in the postprandial period. These differences, which were greatest in the most proximal part of the colon studied, were unexpected, as it had previously been held that the colon is inactive in diarrhoea.

Most other workers have measured only the postprandial response, which was increased in controls and in patients with the irritable bowel syndrome (Kock, Hultén, and Leandoer, 1968; Chaudhary and Truelove, 1961; Connell, Jones, and Rowlands, 1965; Wangel and Deller, 1965) or unchanged in functional diarrhoea (Misiewicz, Connell, and Pontes, 1966). However, consistency of the food may be important because in functional diarrhoea colonic activity increased immediately after the ingestion of a fluid 'meal' (Wangel and Deller, 1965). In the only two previous studies of colonic motility during meals increased prandial activity was observed but the response of our diarrhoeal patients was much greater, and of the constipated patients considerably less, than that of subjects without 
gastrointestinal disease who consumed a similar meal (Pontes, 1969; Holdstock and Misiewicz, 1970).

If the segmenting pressures delay forward propulsion of colonic contents, the excessive and short-lived colonic motor response observed in diarrhoea is at first sight surprising. Such increase in activity might be reasonably expected to delay the entry of faeces into the rectum, yet patients with diarrhoea usually experience the urge to defaecate during or immediately after eating. However, somatic activity as well as the ingestion of food are associated with colonic transit (Holdstock, Misiewicz, Smith, and Rowlands, 1970) so that the colonic response in diarrhoeal patients is inappropriate, because colonic pressure activity returns to previously low basal levels as soon as eating ceases and at a time when somatic activity begins. It is more likely that the exaggerated stimulation of the pelvic colon in diarrhoea is associated with an unusually great increase in propulsive activity of the more proximal colon, and that the brief period of segmentation is unable to prevent the entry of faeces into the rectum, and hence the desire to defaecate. Conversely, since constipated patients show no consistent response during a meal and very little response after it, the stimulus of eating may not be accompanied by any marked increase in propulsive activity in the colon as a whole.

There are some experimental data to support these suggestions. Holdstock et al (1970) have shown that forward propulsion of colonic contents occurs after meals provided that the patient is ambulatory, but the extent of propulsion was not correlated with the bowel habit. Ritchie (1968), using time-lapse cinefluorography, has demonstrated that diarrhoea patients propel colonic contents over considerably greater distances than controls in response to a meal. By contrast no movement of colonic contents in relation to meals could be detected with a radiotelemetering capsule containing a radioactive source in ambulatory constipated patients, some of whom were monitored for up to seven days (Waller, unpublished data). Observations of this nature have not yet been made in diarrhoea.

Despite the marked motor stimulation of the sigmoid colon during the meal, in patients with diarrhoea scrutiny of the pressure records failed to reveal any apparently sequential monophasic wave patterns. Such patterns have been shown to be associated with forward propulsion of colonic contents in the proximal, transverse, and descending colon, but it is not known whether they occur in the sigmoid and rectum (Hardcastle and Mann, 1968; Torsoli, Ramorino, Ammaturo, Capurso, Paoluzi, and Anzini, 1971).

The immediate response of the sigmoid colon in diarrhoeal patients to the ingestion of food was striking and easily apparent without recourse to analysis (Waller and Misiewicz, 1972). The rapidity with which the response occurred suggests a nervous rather than a humoral pathway. Exactly how this is brought about is not clear although Ritchie (1968) has suggested that ileal emptying in diarrhoeal patients is more rapid than in normals. Variations in the rate of gastric emptying may also be a factor. Whatever mechanism brings it about, other evidence derived from comparison of the effects of a meal and of prostigmine suggests that the response of the left colon to a meal is not mediated by cholinergic pathways (Waller and Misiewicz, 1972).

The hypothesis of paradoxical motility in diarrhoea and constipation (Connell, 1962) derives some support from the present observations. However, the lower level of segmenting pressure activity in diarrhoea was found only in the fasting and postprandial periods, but not during the meal. Moreover it should be noted that, despite very careful selection of patients, significant differences between the two clinical groups were attained only with respect to the average levels of activity, there being a considerable overlap between individuals.

We thank Sir Francis Avery Jones and Dr T. D. Kellock for allowing us to study their patients; Dr E. N. Rowlands for helpful advice; Mrs I. M. Prentice, FMAA, medical artist, and Mr A. G. Booker, FPS, medical photographer, for the illustrations; Mr I. D. Hill, MRC Computer Unit, for the computer program for the two-way analysis of variance; Mrs P. A. Stuart for typing the manuscript.

\section{References}

Chaudhary, N. A., and Truelove, S. C. (1961). Human colonic motility: a comparative study of normal subjects, patients with ulcerative colitis, and patients with the irritable colon syndrome I. Resting patterns of motility. Gastroenterology, 40, 1-17.

Connell, A. M. (1962). The motility of the pelvic colon. Part II. Paradoxical motility in diarrhoea and constipation. Gut, 3, 342-348.

Connell, A. M., Hilton, Clare, Irvine, G., Lennard-Jones, J. E., and Misiewicz, J. J. (1965). Variation of bowel habit in two population samples. Brit. med. J., 2, 1095-1099.

Connell, A. M., Jones, F. A., and Rowlands, E. N. (1965). Motility of the pelvic colon. IV. Abdominal pain associated with colonic hypermotility after meals. Gut, 6, 105-112.

Hardcastle, J. D., and Mann, C. V. (1968). Study of large bowel peristalsis. Gut, 9, $512-520$

Holdstock, D. J., and Misiewicz, J. J. (1970). Factors controlling colonic motility: colonic pressures and transit after meals in patients with total gastrectomy, pernicious anaemia or duodenal ulcer. Gut, 11, 100-110.

Holdstock, D. J., Misiewicz, J. J., Smith, T., and Rowlands, E. N. (1970). Propulsion (mass movements) in the human colon and its relationship to meals and somatic activity. Gut, 11, 91-99.

Kern, F., Jr., Almy, T. P., Abbot, F. K., and Bogdonoff, M. D. (1951). The motility of the distal colon in non-specific ulcerative colitis. Gastroenterology, 19, 492-503.

Kock, N. G., Hulten, L., and Leandoer, L. (1968). A study of the 
motility in different parts of the human colon: resting activity response to feeding and to prostigmine. Scand. J. Gastroent., 3, 163-169.

Misiewicz, J. J., Connell, A. M., and Pontes, F. A. (1966). Comparison of the effect of meals and prostigmine on the proximal and distal colon in patients with and without diarrhoea. Gut, 7, 468-473.

Misiewicz, J. J., Waller, Sheila L., and Eisner, M. (1966). Motor responses of human gastrointestinal tract to 5-hydroxytryptamine in vivo and in vitro. Gut, 7, 208-216.

Misiewicz, J. J., Waller, Sheila L., Healy, M. J. R., and Piper, E. A. (1968). Computer analysis of intraluminal pressure records. Gut, 9, 232-236.

Pontes, F. A. (1969). Motilidade do cólon pélvico. Aspectos técnicos e fisiólogicos. MD Thesis, University of Coimbra.

Ritchie, J. A. (1968). Colonic motor activity and bowel function. II. Distribution and incidence of motor activity at rest and after food and carbachol. Gut, 9, 502-511.
Spriggs, E. A., Code, C. F., Bargen, J. A., Curtiss, R. K., and Hightower, N. C., Jr. (1951). Motility of the pelvic colon and rectum of normal persons and patients with ulcerative colitis. Gastroenterology, 19, 480-491.

Torsoli, A., Ramorino, M. L., Ammaturo, M. V., Capurso, L., Paoluzi, P., and Anzini, Fiorella (1971). Mass movements and intracolonic pressures. Amer. J. dig. 1)is., 16, 693-696.

Waller, Sheila L., and Misiewicz, J. J. (1969). Prognosis in the irritablebowel syndrome: a prospective study, Lancet, 2, 753-756.

Waller, Sheila L, and Misiewicz, J. J. (1970). Differences in the action of pentagastrin and gastrin on human gastric and colonic smooth muscle. $R$. $R$. Gastroent, 2, 159-166.

Waller, Sheila L., and Misiewicz, J. J. (1972). Colonic motility in constipation or diarrhoea. Scand. J. Gastroent., 7, 93-96.

Wangel, A. G., and Deller, D. J. (1965). Intestinal motility in man. Part III. Mechanisms of constipation and diarrhea with particular reference to the irritable colon syndrome. Gastroenterology, 48, 69-84.

The September 1972 Issue

\section{THE SEPTEMBER 1972 ISSUE CONTAINS THE FOLLOWING PAPERS}

Non-dietary lipid in the intestinal lumen P. B. COTTON

Lipid absorption, bile acids, and cholesterol metabolism in patients with chronic liver disease T. A. MIETTINEN

Corticosteroids in liver disease: Studies on the biological conversion of prednisone to prednisolone and plasma protein binding L. W. POWELL AND ELIZABETH AXELSEN

Antidepressants and liver disease M. HILARY MORGAN AND A. E. READ

Serum $\gamma$-glutamyl transpeptidase activity in liver disease J. B. WHITFIELD, R. E. POUNDER, G. NEALE, AND D. W. MOSS

Effect of cholecystokinin-pancreozymin and secretin on the volume, composition, and enzymatic activity of hepatic bile in rabbits $s$. KIRCHMAYER, A. TARNAWSKI, H. DROŻDż, AND K. CICHECKA

Salivary secretion in duodenal ulcer disease ANDRÉ L. BLUM AND JOEL W. WOODALL

Copies are still available and may be obtained from the PUBLISHING MANAGER,

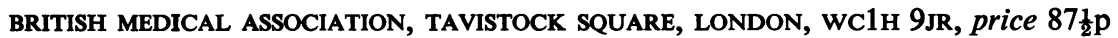

coeliac disease T, WALLINGTON, A. B. AJDUKIEWICZ, A. E. READ, AND J. VERRIER JONES

A comparison of Boots and GIH secretin as stimuli of pancreatic secretion in human subjects with or without chronic pancreatitis L. V. GUTIERREZ AND J. H. BARON

Synthetic peptides in the diagnosis of exocrine pancreatic insufficiency in animals A. R. IMONDI, R. P. STRADLEY, AND R. WOLGEMUTH

\section{Technique}

A new disposable probe for recording intraluminal pressure and electric potentials in the human gastrointestinal tract SVEN DORPH, ADAM øIGAARD, AND MICHAEL KRAKSHOLM

Progress report Membrane digestion A. M. UGOLEV

Progress report Renal changes in cirrhosis MICHAEL KEW

Notes and activities 